Article

\title{
Growth of Yellowtail (Seriola quinqueradiata) Fed on a Diet Including Partially or Completely Defatted Black Soldier Fly (Hermetia illucens) Larvae Meal
}

\author{
Atsushi Ido $^{1}$ (D), Muhammad-Fariz-Zahir Ali ${ }^{1}$ (D), Takayuki Takahashi ${ }^{1}$, Chiemi Miura ${ }^{1,2}$ and Takeshi Miura ${ }^{1, *(\mathbb{D})}$ \\ 1 Graduate School of Agriculture, Ehime University, Matsuyama 790-8566, Japan; ido@agr.ehime-u.ac.jp (A.I.); \\ fariz290392@gmail.com (M.-F.-Z.A.); takataka@dpc.ehime-u.ac.jp (T.T.); c.miura.6u@it-hiroshima.ac.jp (C.M.) \\ 2 Department of Global Environment Studies, Faculty of Environmental Studies, \\ Hiroshima Institute of Technology, Saeki 731-5193, Japan \\ * Correspondence: miutake@agr.ehime-u.ac.jp; Tel.: +81-89-946-3684
}

check for

updates

Citation: Ido, A.; Ali, M.-F.-Z.; Takahashi, T.; Miura, C.; Miura, T. Growth of Yellowtail (Seriola quinqueradiata) Fed on a Diet Including Partially or Completely Defatted Black Soldier Fly (Hermetia illucens) Larvae Meal. Insects 2021, 12, 722. https://doi.org/10.3390/ insects12080722

Academic Editor: Juan A.

Morales-Ramos

Received: 19 July 2021

Accepted: 11 August 2021

Published: 12 August 2021

Publisher's Note: MDPI stays neutral with regard to jurisdictional claims in published maps and institutional affiliations.

Copyright: (c) 2021 by the authors. Licensee MDPI, Basel, Switzerland. This article is an open access article distributed under the terms and conditions of the Creative Commons Attribution (CC BY) license (https:// creativecommons.org/licenses/by/ $4.0 /)$.
Simple Summary: Insects which can be reared artificially, such as the black soldier fly, housefly or yellow mealworm are considered as promising feed sources for sustainable aquaculture. The present study is the first to reveal the potential of diets containing insect meal for juvenile yellowtail. The growth of fish fed diets in which fish meal was replaced by $10-30 \%$ partially defatted black soldier fly larvae meal was decreased in accordance with the content of the larvae meal. On the other hand, growth of fish with a diet including $20 \%$ completely defatted larvae meal was equivalent to that with a diet of the partially defatted larvae meal. Thus, the fat fraction of black solider fly larvae could cause growth retardation of yellowtail, and the defatting process of the insect meal may be important in the manufacture of black soldier fly larvae meal for yellowtail.

Abstract: Against a background of increased demand for fish meal (FM), black soldier fly larva is a promising alternative feed source for sustainable aquaculture. Yellowtail, the most popular farmed fish in Japan, is a carnivorous fish; therefore, it requires a high proportion of FM in its diet. This study represents the first example of yellowtail fed on a diet including insect meal as a replacement for FM. Partially defatted black soldier fly meal (PDBM) comprised $49.0 \%$ crude protein and $23.2 \%$ crude fat, while completely defatted black soldier fly meal (CDBM) contained less than $10 \%$ crude fat, as the same level as FM was achieved with defatting PDBM using hexane. In feeding trials, growth of the fish was reduced in accordance with PDBM content: 10\%, 20\%, and 30\% in their diet. Although a diet including $8 \%$ CDBM (with the same protein composition as $10 \%$ PDBM) also resulted in decreased fish growth, growth with a diet including 16\% CDBM (with the same protein composition as $20 \%$ PDBM) was significantly higher than that of $20 \%$ PDBM, and equivalent to that of $10 \%$ PDBM. Therefore, even $10 \%$ of partially or completely black soldier fly larvae meal in diets inhibited growth in juvenile yellowtail, and we found that removal of the fat fraction could improve fish growth.

Keywords: yellowtail; black soldier fly; defatting; fish meal replacement; lauric acid; fat fraction

\section{Introduction}

Fish meal (FM) is an essential component in aquaculture feed. The use of the aquaculture feed is estimated to keep increasing until 2025 due to a rapid growth in world aquaculture production, and the price of FM has been steadily increasing [1]. About 30 million tons of wild-caught pelagic fish per year were used for FM production, and pressure on the fish from fishing is a serious concern for marine ecosystems [2]. Thus, a development of an alternative feed source for cultured fish is an urgent issue.

Insects are thought to be a potential feed source for sustainable aquaculture [3-5]. Black soldier fly (BSF) (Hermetia illucens) larvae are one of the most promising insect species used for fish feed. BSF larvae can be artificially reared in a highly efficient way using 
organic by-products, and they contain a high proportion of protein [3]. BSF larvae offer more than just a protein source. A novel bioactive polysaccharide that can stimulate innate immunity was identified in BSF larvae [6], while dietary BSF larvae were reported to provide improvements in immunity and disease resistance in barramundi (Lates calcarifer) [7] and European seabass (Dicentrarchus labrax) [8].

Aside from freshwater species, however, the replacement of FM with BSF larvae meal has not always been successful in carnivorous marine fish species. The complete replacement of $10 \%$ of FM with $14.8 \%$ of BSF larvae meal resulted in no difference in growth in Atlantic salmon (Salmo salar) $[9,10]$, while the replacement of dietary FM with more than $16.5 \%$ BSF larvae meal reduced the growth of juvenile turbot (Psetta maxima) [11]. A dietary inclusion level of BSF larvae meal that does not adversely affect Japanese seabass (Lateolabrax japonicus) and European seabass is just 19.2\% and 19.5\% of their diet, respectively [12-14]. In these studies, the factors of BSF larvae meal that affected marine fish growth remained unknown.

The aquaculture of fish belonging to the genus Seriola is becoming important worldwide [15], with yellowtail (Seriola quinqueradiata) in particular the most popular and important cultured fish in Japan [16]. The problem in yellowtail farming is that their diets rely on a high proportion of FM, and little progress has been made in reducing the amount of FM included, and commercial pelleted diet for yellowtail still contains 50-60\% FM [17-19]. Plant protein, such as soybean meal, has been tried but was found to suppress the secretion of digestive enzymes in yellowtail $[20,21]$. Therefore, novel animal protein sources that are highly palatable to yellowtail are urgently needed. The replacement of FM with insect meal has been investigated for many cultured fish species; however, the potential of insect meal in feed for yellowtail has not yet been demonstrated.

This study is the first report of juvenile yellowtail being fed diets including insect meal as a replacement for FM. In the study, the effects of partially defatted and completely defatted BSF larvae meals on the growth of yellowtail body have been assessed.

\section{Materials and Methods}

\subsection{Ethics Statement}

Animal experiments were carried out following the guidelines of Ehime University. The study protocol was approved by the Institutional Animal Care and Use Committee (IACUC) of Ehime University (Permit Number: 3908).

\subsection{Defatting of Black Soldier Fly Larvae Meal}

Partially defatted BSF larvae meal (PDBM) produced in Malaysia was kindly provided by Shintoa Corporation (Tokyo, Japan). The defatting of BSF larvae was conducted using press. Briefly, BSF larvae reared with agricultural by-products were washed, dried, ground, and pressed for defatting. To remove the fat fraction from PDBM, we defatted PDBM with hexane by the method that we previously described $[22,23]$. Briefly, PDBM was suspended with a 4-fold greater volume of hexane, and then incubated overnight at room temperature with occasional gentle agitation. The supernatant was removed with filtration, then the residue was heated at $60^{\circ} \mathrm{C}$ for 1 day or more until dry and completely defatted BSF larvae meal (CDBM) was obtained.

\subsection{Feed Formulation of Experimental Diets}

We devised feed formulations based on results of proximate, amino acid, and fatty acid analyses (Tables 1 and 2). In this study, the diets were formulated not only to be isonitrogenous (46-48\% crude protein), but also to adjust fatty acid composition between the experimental diets. 
Table 1. Formulation of experimental diets in feeding trial 1.

\begin{tabular}{|c|c|c|c|c|c|}
\hline Ingredients & Control & Control+L & 10PD & 20PD & 30PD \\
\hline Fish meal $(65 \% \mathrm{CP})^{1}$ & 64.00 & 64.00 & 56.87 & 49.75 & 42.62 \\
\hline PDBM & - & - & 10.00 & 20.00 & 30.00 \\
\hline Fish oil & 8.00 & 8.00 & 8.76 & 9.51 & 10.27 \\
\hline Palm kernel oil & - & 4.35 & 2.90 & 1.45 & - \\
\hline Corn oil & 4.35 & - & - & - & - \\
\hline Starch & 13.15 & 13.15 & 10.97 & 8.79 & 6.61 \\
\hline Taurine & 1.00 & 1.00 & 1.00 & 1.00 & 1.00 \\
\hline Vitamin mix ${ }^{2}$ & 0.80 & 0.80 & 0.80 & 0.80 & 0.80 \\
\hline Mineral mix ${ }^{3}$ & 0.40 & 0.40 & 0.40 & 0.40 & 0.40 \\
\hline Choline chloride & 0.10 & 0.10 & 0.10 & 0.10 & 0.10 \\
\hline Vitamin $C$ derivatives & 0.10 & 0.10 & 0.10 & 0.10 & 0.10 \\
\hline $\mathrm{NaH}_{2} \mathrm{PO}_{4}$ & 0.80 & 0.80 & 0.80 & 0.80 & 0.80 \\
\hline $\mathrm{KH}_{2} \mathrm{PO}_{4}$ & 0.80 & 0.80 & 0.80 & 0.80 & 0.80 \\
\hline Calcium lactate & 1.50 & 1.50 & 1.50 & 1.50 & 1.50 \\
\hline $\mathrm{CMC}^{4}$ & 5.00 & 5.00 & 5.00 & 5.00 & 5.00 \\
\hline Total & 100.00 & 100.00 & 100.00 & 100.00 & 100.00 \\
\hline \multicolumn{6}{|l|}{ Proximate composition (\%) } \\
\hline Moisture & 3.3 & 3.2 & 4.0 & 3.7 & 4.8 \\
\hline Crude protein & 46.7 & 46.5 & 46.2 & 46.1 & 45.1 \\
\hline Crude fat & 18.8 & 17.6 & 17.4 & 17.5 & 20.2 \\
\hline Ash & 11.1 & 11.2 & 11.1 & 11.0 & 11.0 \\
\hline NFE + crude fiber ${ }^{5}$ & 20.1 & 21.4 & 21.3 & 21.7 & 19.0 \\
\hline \multicolumn{6}{|l|}{$\begin{array}{l}\text { Fatty acid composition } \\
\text { ( } \% \text { on a dried basis) }\end{array}$} \\
\hline $\mathrm{C} 12: 0$ & 0.61 & 2.68 & 2.74 & 2.79 & 2.85 \\
\hline $\mathrm{C} 16: 0$ & 2.85 & 2.73 & 2.95 & 3.18 & 3.40 \\
\hline C18:1 & 4.21 & 3.60 & 4.39 & 5.18 & 5.97 \\
\hline C22:6 & 2.35 & 2.35 & 2.35 & 2.35 & 2.35 \\
\hline
\end{tabular}

${ }^{1}$ Peruvian fish meal provided by Shintoa Corporation, Tokyo, Japan. ${ }^{2}$ Vitamin mix (per $1000 \mathrm{mg}$ of mix): thiamin $\cdot \mathrm{HCl}, 8.0 \mathrm{mg}$; riboflavin, $20.0 \mathrm{mg}$; pyridoxine $\cdot \mathrm{HCl}, 10.0 \mathrm{mg}$; nicotinic acid, $80.0 \mathrm{mg}$; calcium d-pantothenate, $40.0 \mathrm{mg}$; biotin (2\%), $40.0 \mathrm{mg}$; folic acid, $1.5 \mathrm{mg}$; cyanocobalamin $(2 \%), 12.5 \mathrm{mg}$; sodium calcium ascorbyl2-phosphate, $200.0 \mathrm{mg}$; inositol, $200.0 \mathrm{mg}$; retinol powder (1,000,000 IU/g), $5.0 \mathrm{mg}$; cholecalciferol powder (500,000 IU/g), $1.0 \mathrm{mg}$; tocopherol (50\%), $150.0 \mathrm{mg}$; menadion, $4.0 \mathrm{mg}$; cellulose, $228.0 \mathrm{mg}$ (SINRA, Fukuoka, Japan). ${ }^{3}$ Mineral mix (per $100 \mathrm{~g}$ of mix): $\mathrm{NaCl}, 5.0 \mathrm{~g} ; \mathrm{MgSO}_{4}, 74.5 \mathrm{~g}$; $\mathrm{FeC}_{6} \mathrm{H}_{5} \mathrm{O} 7 \cdot{ }_{\mathrm{n}} \mathrm{H}_{2} \mathrm{O}, 7.5 \mathrm{~g} ; \mathrm{C} 4 \mathrm{H} 2 \mathrm{FeO} 4,5.0 \mathrm{~g}$; $\mathrm{ZnSO}_{4} \cdot 7 \mathrm{H}_{2} \mathrm{O}, 1765 \mathrm{mg} ; \mathrm{MnSO}_{4} \cdot 5 \mathrm{H}_{2} \mathrm{O}, 810 \mathrm{mg} ; \mathrm{CuSO}_{4} \cdot 5 \mathrm{H}_{2} \mathrm{O}, 155 \mathrm{mg} ; \mathrm{AlCl}_{2} \cdot 6 \mathrm{H}_{2} \mathrm{O}, 50 \mathrm{mg} ; \mathrm{CoCl}_{2} \cdot 6 \mathrm{H}_{2} \mathrm{O}, 5 \mathrm{mg}$ $\mathrm{KlO}_{3}, 15 \mathrm{mg}$; $\left(\mathrm{CH}_{3} \mathrm{CHOCOO}\right)_{2} \mathrm{Ca} \cdot 5 \mathrm{H}_{2} \mathrm{O}, 2200 \mathrm{mg}$; Cellulose, $3.0 \mathrm{~g}$ (SINRA, Fukuoka, Japan). ${ }^{4}$ Carboxymethylcellulose as a pelleting agent. ${ }^{5}$ Nitrogen free extract $($ NFE$)+$ crude fiber $=100-($ crude protein + crude fat + ash). Values for proximate composition were means of duplicate analyses. Values for fatty acid composition were calculated using the manufacture's values. Abbreviations: PDBM, partially defatted black soldier fly larvae meal.

In feeding trial 1, diets including 64\% FM were used for two control groups, and three test diets were formulated to contain 10\% PDBM (10PD), 20\% PDBM (20PD), and 30\% PDBM (30PD), replacing $11 \%, 22 \%$, and $33 \%$ of FM in the control diets, respectively. As the fat fraction of PDBM included $29.2 \%$ lauric acid in the total fatty acids, palm kernel oil, which is also rich in lauric acid, was added to Control+L, 10PD, 20PD, and 30PD except for the Control to be an equivalent level to lauric acid, while corn oil was contained in the Control diet to equalize the total fat content. Furthermore, the fish oil content was increased in diets including PDBM in consideration of the fat fraction included in FM to be an equivalent level of fat from fish in each diet (Table 1).

In feeding trial 2, test diets including 10\% PDBM (10PD) and 10\% CDBM (10CD) were formulated to replace $11 \%$ of FM, and 20\% PDBM (20PD) and 20\% CDBM (20CD) were formulated to replace $22 \%$ of FM in the control diets, respectively. Palm kernel oil was added to Control+L, 10PD, 10CD, 20PD, and 20CD except for the Control to be an equivalent level to $\mathrm{C} 12: 0$, while corn oil was included in the Control diet to equalize the total fat content. The fish oil content was increased in diets including PDBM or CDBM to make fat from fish in each diet equal. In other words, all diets contained equivalent 
levels of fish-derived fat, and a diet of Control+L and test diets including PDBM or CDBM contained equivalent levels of lauric acid (Table 2).

Table 2. Formulation of experimental diets in feeding trial 2.

\begin{tabular}{|c|c|c|c|c|c|c|}
\hline Ingredients & Control & Control+L & 10PD & 20PD & 10CD & $20 \mathrm{CD}$ \\
\hline $\begin{array}{l}\text { Fish meal } \\
(65 \% \mathrm{CP})^{1}\end{array}$ & 64.00 & 64.00 & 57.18 & 50.36 & 57.18 & 50.36 \\
\hline PDBM & - & - & 10.00 & 20.00 & - & - \\
\hline CDBM & - & - & - & - & 8.02 & 16.03 \\
\hline Fish oil & 8.00 & 8.00 & 8.74 & 9.49 & 8.74 & 9.49 \\
\hline Palm kernel oil & - & 4.37 & 2.19 & - & 3.74 & 3.11 \\
\hline Corn oil & 4.37 & - & - & - & - & - \\
\hline Starch & 9.00 & 9.00 & 9.00 & 9.00 & 9.00 & 9.00 \\
\hline Cellulose & 4.13 & 4.13 & 2.39 & 0.65 & 2.82 & 1.51 \\
\hline Taurine & 1.00 & 1.00 & 1.00 & 1.00 & 1.00 & 1.00 \\
\hline Vitamin mix ${ }^{2}$ & 0.80 & 0.80 & 0.80 & 0.80 & 0.80 & 0.80 \\
\hline Mineral mix ${ }^{3}$ & 0.40 & 0.40 & 0.40 & 0.40 & 0.40 & 0.40 \\
\hline Choline chloride & 0.10 & 0.10 & 0.10 & 0.10 & 0.10 & 0.10 \\
\hline Vitamin $C$ derivatives & 0.10 & 0.10 & 0.10 & 0.10 & 0.10 & 0.10 \\
\hline $\mathrm{NaH}_{2} \mathrm{PO}_{4}$ & 0.80 & 0.80 & 0.80 & 0.80 & 0.80 & 0.80 \\
\hline $\mathrm{KH}_{2} \mathrm{PO}_{4}$ & 0.80 & 0.80 & 0.80 & 0.80 & 0.80 & 0.80 \\
\hline Calcium lactate & 1.50 & 1.50 & 1.50 & 1.50 & 1.50 & 1.50 \\
\hline $\mathrm{CMC}^{4}$ & 5.00 & 5.00 & 5.00 & 5.00 & 5.00 & 5.00 \\
\hline Total & 100.00 & 100.00 & 100.00 & 100.00 & 100.00 & 100.00 \\
\hline \multicolumn{7}{|l|}{ Proximate composition (\%) } \\
\hline Moisture & 4.3 & 4.6 & 4.0 & 4.0 & 3.8 & 4.2 \\
\hline Crude protein & 44.8 & 44.7 & 46.5 & 46.1 & 45.9 & 44.4 \\
\hline Crude fat & 19.4 & 19.1 & 19.8 & 19.7 & 19.1 & 18.6 \\
\hline Ash & 2.1 & 2.0 & 2.2 & 2.1 & 2.0 & 1.9 \\
\hline NFE + crude fiber ${ }^{5}$ & 29.5 & 29.6 & 27.6 & 28.1 & 29.3 & 30.9 \\
\hline \multicolumn{7}{|l|}{$\begin{array}{l}\text { Fatty acid composition } \\
\text { (\% on a dried basis) }\end{array}$} \\
\hline C12:0 & 0.61 & 2.69 & 2.40 & 2.10 & 2.61 & 2.52 \\
\hline C16:0 & 2.29 & 0.39 & 0.37 & 0.34 & 0.98 & 1.58 \\
\hline C18:1 & 5.05 & 4.99 & 4.98 & 4.98 & 5.06 & 5.14 \\
\hline $\mathrm{C} 22: 6$ & 2.35 & 2.35 & 2.35 & 2.35 & 2.35 & 2.35 \\
\hline
\end{tabular}

${ }^{1}$ Peruvian fish meal provided by Shintoa Corporation, Tokyo, Japan. ${ }^{2}$ Vitamin mix (per $1000 \mathrm{mg}$ of mix): thiamin $\cdot \mathrm{HCl}, 8.0 \mathrm{mg}$; riboflavin, $20.0 \mathrm{mg}$; pyridoxine $\cdot \mathrm{HCl}, 10.0 \mathrm{mg}$; nicotinic acid, $80.0 \mathrm{mg}$; calcium d-pantothenate, $40.0 \mathrm{mg}$; biotin $(2 \%), 40.0 \mathrm{mg}$; folic acid, $1.5 \mathrm{mg}$; cyanocobalamin $(2 \%), 12.5 \mathrm{mg}$; sodium calcium ascorbyl2-phosphate, $200.0 \mathrm{mg}$; inositol, $200.0 \mathrm{mg}$; retinol powder (1,000,000 IU/g), $5.0 \mathrm{mg}$; cholecalciferol powder (500,000 IU/g), $1.0 \mathrm{mg}$; tocopherol (50\%), $150.0 \mathrm{mg}$; menadion, $4.0 \mathrm{mg}$; cellulose, $228.0 \mathrm{mg}$ (SINRA, Fukuoka Japan). ${ }^{3}$ Mineral mix (per $100 \mathrm{~g}$ of mix): $\mathrm{NaCl}, 5.0 \mathrm{~g} ; \mathrm{MgSO}_{4}, 74.5 \mathrm{~g} ; \mathrm{FeC}_{6} \mathrm{H}_{5} \mathrm{O} 7 \cdot{ }_{n} \mathrm{H}_{2} \mathrm{O}, 7.5 \mathrm{~g} ; \mathrm{C} 4 \mathrm{H} 2 \mathrm{FeO} 4,5.0$ g; $\mathrm{ZnSO}_{4} \cdot 7 \mathrm{H}_{2} \mathrm{O}, 1765 \mathrm{mg} ; \mathrm{MnSO}_{4} \cdot 5 \mathrm{H}_{2} \mathrm{O}, 810 \mathrm{mg} ; \mathrm{CuSO}_{4} \cdot 5 \mathrm{H}_{2} \mathrm{O}, 155 \mathrm{mg} ; \mathrm{AlCl}_{2} \cdot 6 \mathrm{H}_{2} \mathrm{O}, 50 \mathrm{mg} ; \mathrm{CoCl}_{2} \cdot 6 \mathrm{H}_{2} \mathrm{O}, 5 \mathrm{mg}$; $\mathrm{KlO}_{3}, 15 \mathrm{mg}$; $\left(\mathrm{CH}_{3} \mathrm{CHOCOO}\right)_{2} \mathrm{Ca} \cdot 5 \mathrm{H}_{2} \mathrm{O}, 2200 \mathrm{mg}$; Cellulose, $3.0 \mathrm{~g}$ (SINRA, Fukuoka, Japan). ${ }^{4}$ Carboxymethylcellulose as a pelleting agent. ${ }^{5}$ Nitrogen free extract (NFE) + crude fiber $=100-$ (crude protein + crude fat + ash). Values for proximate composition were means of duplicate analyses. Values for fatty acid composition were calculated using the manufacture's values. Abbreviations: PDBM, partially defatted black soldier fly larvae meal; CDBM, completely defatted black soldier fly larvae meal.

\subsection{Feeding Trials}

Juvenile yellowtails (average body weight: $0.7 \mathrm{~g}$ ) were kindly provided by Yamasaki Giken Co. Ltd. (Kochi, Japan). The fish were fed a commercial diet (Marubeni Nisshin Feed Co., Ltd., Tokyo, Japan) for about 1 month for acclimation. The ingredients of the experimental diets were well mixed after adding water, granulated to 1.6-3.0 mm diameter, and then air-dried at $60-70{ }^{\circ} \mathrm{C}$ for more than 1 day.

For feeding trial 1, at the beginning of the trial, 30 fish (average fork length: $6.6 \mathrm{~cm}$; average body weight: $2.9 \mathrm{~g}$ ) were distributed to each of ten $200 \mathrm{~L}$ tanks that used a flowthrough system. Two tanks per group were set. The fish were fed to satiation twice a day, 6 days per week. The fish were cultivated for 84 days (12 weeks). The water temperature varied between $18.8-24.8{ }^{\circ} \mathrm{C}$ during the trial. The fork lengths (FL) and body weights (BW) were measured four times (at the start, after 3 weeks, after 6 weeks, and after 12 weeks) under anesthesia with 2-phenoxy ethanol (Nacalai Tesque, Kyoto, Japan). Then, 28 fish per group were randomly selected and their intestinal lengths were measured. 
In feeding trial 2, at the beginning of the trial, 30 fish (average fork length: $7.7 \mathrm{~cm}$; average body weight: $5.3 \mathrm{~g}$ ) were distributed to each of twelve $200 \mathrm{~L}$ tanks that used a flow-through system. Two tanks per group were set. The fish were fed to satiation twice a day, and 6 days per week. The fish were cultivated for 35 days ( 5 weeks). The water temperature varied between $18.9-22.6^{\circ} \mathrm{C}$ during the trial. $\mathrm{FL}$ and $\mathrm{BW}$ were measured three times (at the start, after 2.5 weeks and after 5 weeks) under anesthesia with 2-phenoxy ethanol (Nacalai Tesque, Kyoto, Japan).

FL gain, BW gain, FL gain rate, BW gain rate, specific growth rate (SGR), and feed conversion ratio (FCR) were calculated as follows:

$$
\begin{gathered}
\text { FL gain rate }(\%)=(\mathrm{FL} \text { at measurement }- \text { initial } \mathrm{FL}) / \text { initial } \mathrm{FL} \times 100, \\
\mathrm{BW} \text { gain rate }(\%)=(\mathrm{BW} \text { at measurement }- \text { initial } \mathrm{BW}) / \text { initial } \mathrm{BW} \times 100, \\
\mathrm{SGR}, \% \text { day }^{-1}=[(\mathrm{ln} \text { final } \mathrm{BW}-\ln \text { initial } \mathrm{BW}) / \text { number of feeding days }] \times 100, \\
\mathrm{FCR}=\text { total feed intake } /(\text { final } \mathrm{BW}-\text { initial } \mathrm{BW})
\end{gathered}
$$

Measurements from individual fishes were used to obtain the FL, BW, FL gain, BW gain, FL gain rate, and BW gain rate in the feeding test groups, and values in the duplicate tanks were used to obtain the total feed intake per fish and FCR in each study group. Intestinal length ratio (\%) was calculated by intestinal length/final FL $\times 100$.

\subsection{Proximate Composition, Amino Acid, and Fatty Acid Analysis}

The proximate composition, amino acids, and fatty acids of the experimental diets or their ingredients were analyzed with the Association of Analytical Communities (AOAC) methods [24]. Briefly, the content of crude protein was analyzed with the Kjeldahl method [24]. "Kjeltab" (containing $\mathrm{K}_{2} \mathrm{SO}_{4}$ ) was added to the samples, and the samples were digested in a block heater (Tecator ${ }^{\mathrm{TM}}$ Digestion Systems 2520, FOSS). The nitrogen content was analyzed using an auto analyzer (Kjeltec ${ }^{\mathrm{TM}}$ 8400, FOSS). The crude protein was obtained based on the calculation from the nitrogen content with the nitrogen-protein conversion factor, 6.25. Crude fat was analyzed with the Soxhlet extraction method [24]. Extraction from the samples was conducted with petroleum ether in an Automated extractor (Soxtec ${ }^{\mathrm{TM}} 8000$, FOSS). The content of ash was analyzed with an electric furnace (MMF-1, AS ONE).

Proteinogenic amino acid composition in the samples was analyzed with an automated amino acid analyzer (Shimadzu, Kyoto, Japan) after hydrochloric hydrolysis with sodium chloride. For methionine and cystine, the samples were oxidized with performic acid prior to hydrochloric hydrolysis. For tryptophan, samples were prepared with barium hydroxide octahydrate and thiodiethylene glycol prior to hydrolysis with sodium chloride, then analyzed using high-performance liquid chromatography. Fatty acid composition in samples were prepared with saponification and analyzed using gas chromatography with a method described in food labeling standards produced by the Consumer Affairs Agency Japan (CAA, 2015). The analysis of proteinogenic amino acids and fatty acids was conducted by the Japan Food Research Laboratories (Osaka, Japan).

\subsection{Statistical Analysis}

For FL, BW, FL gain rate, BW gain rate, and intestinal length ratio on the feeding trial 1 and 2, statistically significant differences among the control and test groups were identified by the Kruskal-Wallis test and Mann-Whitney test with Holm's correction for post hoc comparison $(p<0.05)$. The tests were conducted using R software (https: / / www.r-project.org (accessed on 10 May 2021)). 


\section{Results}

3.1. Analysis of Proximate Composition, Amino Acid Profiles, and Fatty Acid Profiles

The proximate compositions of BSF larvae meals used in this study are shown in Table 3. PDBM contained $49.0 \%$ crude protein (CP) and $23.2 \%$ crude fat (CF). CDBM obtained from PDBM defatted with hexane contained $8.3 \% \mathrm{CF}$, which was comparable with that present in FM. Although PDBM covered essential amino acids required for fish growth and survival (Table 4), there was a big difference between oil from PDBM and fish oil in terms of their fatty acid profiles. Compared with fish oil, oil from PDBM was rich in saturated fatty acids, especially lauric acid (C12:0), and lacking in polyunsaturated fatty acids (Table 5).

Table 3. Proximate composition of black soldier fly larvae meal in this study.

\begin{tabular}{cccc}
\hline $\begin{array}{c}\text { Proximate Composition } \\
\text { (\% on a Dried Basis) }\end{array}$ & PDBM & CDBM & FM \\
\hline Crude protein & 49.0 & 60.6 & 72.5 \\
Crude fat & 23.2 & 8.3 & 8.6 \\
Ash & 1.8 & 2.1 & 18.5
\end{tabular}

Values for proximate composition were means of duplicate analysis. Abbreviations: PDBM, partially defatted black soldier fly larvae meal; CDBM, completely defatted black soldier fly larvae meal; FM, fish meal.

Table 4. Amino acid (AA) profile of black soldier fly larvae meal in this study.

\begin{tabular}{ccc}
\hline Components (\% of Total AAs) & PDBM & FM \\
\hline Ala & 8.6 & 7.0 \\
Arg & 4.7 & 6.5 \\
Asp & 9.1 & 9.5 \\
Cys & 1.0 & 1.0 \\
Glu & 13.0 & 13.2 \\
Gly & 6.0 & 7.7 \\
His & 2.7 & 3.3 \\
Ile & 4.6 & 4.3 \\
Leu & 7.4 & 8.2 \\
Lys & 6.5 & 8.3 \\
Met & 1.8 & 3.1 \\
Phe & 4.4 & 4.3 \\
Pro & 6.4 & 5.0 \\
Ser & 4.4 & 4.3 \\
Thr & 4.2 & 4.6 \\
Trp & 1.6 & 1.3 \\
Tyr & 6.8 & 3.3 \\
Val & 6.7 & 5.2 \\
\hline
\end{tabular}

Abbreviations: PDBM, partially defatted black soldier fly larvae meal; FM, fish meal.

Table 5. Fatty acid (FA) profile of black soldier fly larvae meal in this study.

\begin{tabular}{ccc}
\hline Components $(\%$ of Total FAs) & Oil from PDBM & Fish Oil \\
\hline Saturated fatty acid & & \\
$10: 0$ & 0.8 & - \\
$12: 0$ & 29.2 & 4.1 \\
$14: 0$ & 7.6 & - \\
$15: 0$ & 0.1 & 0.5 \\
$16: 0$ & 14.0 & 15.6 \\
$17: 0$ & 0.1 & 0.7 \\
$18: 0$ & 2.7 & 3.6 \\
$20: 0$ & 0.2 & 0.3 \\
$22: 0$ & - & - \\
Total & 54.7 & 24.8 \\
\hline
\end{tabular}


Table 5. Cont.

\begin{tabular}{|c|c|c|}
\hline Components (\% of Total FAs) & Oil from PDBM & Fish Oil \\
\hline \multicolumn{3}{|l|}{ Monounsaturated fatty acid } \\
\hline $14: 1$ & 0.1 & - \\
\hline $16: 1$ & 1.2 & 5.0 \\
\hline $17: 1$ & 0.1 & 0.5 \\
\hline $18: 1$ & 40.2 & 19.4 \\
\hline $20: 1$ & - & 5.2 \\
\hline $22: 1$ & - & 5.0 \\
\hline $24: 1$ & - & 0.6 \\
\hline Total & 41.5 & 35.7 \\
\hline \multicolumn{3}{|l|}{$\begin{array}{l}\text { Polyunsaturated fatty acid } \\
\qquad \omega-3 \text { fatty acid }\end{array}$} \\
\hline $16: 3 n-3$ & 0.1 & - \\
\hline $18: 3 n-3$ & 3.5 & 1.0 \\
\hline $20: 3 n-3$ & - & 0.2 \\
\hline $20: 4 n-3$ & - & 0.7 \\
\hline $20: 5 n-3$ & - & 7.5 \\
\hline $21: 5 n-3$ & - & 0.3 \\
\hline $22: 5 n-3$ & - & 1.9 \\
\hline $22: 6 n-3$ & - & 15.7 \\
\hline Total & 3.6 & 27.3 \\
\hline \multicolumn{3}{|l|}{$\omega-6$ fatty acid } \\
\hline $18: 2 n-6$ & - & 2.8 \\
\hline $20: 2 n-6$ & - & 0.3 \\
\hline $20: 3 n-6$ & - & 0.2 \\
\hline $20: 4 n-6$ & - & 1.1 \\
\hline $22: 5 n-6$ & - & 0.6 \\
\hline Total & - & 5.0 \\
\hline \multicolumn{3}{|l|}{ Others } \\
\hline $16: 2$ & - & 0.3 \\
\hline $16: 3$ & - & 0.2 \\
\hline $16: 4$ & - & 0.3 \\
\hline Total & - & 0.8 \\
\hline Not identified & 0.2 & 4.3 \\
\hline
\end{tabular}

\subsection{Feeding Trials with Juvenile Yellowtail}

Two feeding trials with juvenile yellowtail were conducted. In the first trial, feeds including 10\%, 20\%, and 30\% PDBM were evaluated. In consideration of lauric acid included in BSF larvae meal, we set two control diets; the Control was free from PDBM and lauric acid and the Control+L contained lauric acid at the same level as 10PD, 20PD, and 30PD. The DHA (C22:6) content was equal in all diets (Table 4). Although all diets were isonitrogenous and isolipidic, the growth of fish fed Control+L containing lauric acid was significantly inferior to that of the Control, and the growth decreased with PDBM content. FCR slightly increased in fish fed diets that included PDBM (Table 6; Figure 1). The intestinal length ratio at 12 weeks in each group is shown in Figure 2. The ratios in the Control+L, 20PD, and 30PD groups were significantly higher than that of the Control. Compared with fish fed on the Control diet, the ratio tended to increase with PDBM content.

In the next trial, diets containing CDBM were compared with diets containing PDBM. Growths in fish fed on diets containing PDBM and CDBM decreased significantly comparing with growth in the Control and Control+L groups, and fish growth declined according to the amount of PDBM. However, growth in fish fed on diets including 20\% CDBM was similar to that in groups fed on 10\% CDBM and PDBM, and significantly higher than that in the group fed on 20\% PDBM (Table 7; Figure 3). There was also a significant difference between the two Control diets in this trial, Control+L containing lauric acid in BW gain rate (Figure 3). FCR was almost the same in all groups. 
Table 6. Growth of juvenile yellowtail in feeding trial 1.

\begin{tabular}{|c|c|c|c|c|c|c|}
\hline & & Control & Control+L & 10PD & 20PD & 30PD \\
\hline \multirow[t]{4}{*}{$N$} & Initial & 60 & 60 & 60 & 60 & 60 \\
\hline & 3 wks & 60 & 60 & 59 & 60 & 60 \\
\hline & 6 wks & 60 & 58 & 57 & 43 & 57 \\
\hline & 12 wks & 59 & 58 & 54 & 41 & 56 \\
\hline \multirow[t]{4}{*}{$\mathrm{FL}(\mathrm{cm})$} & Initial & $6.6 \pm 0.3^{a}$ & $6.6 \pm 0.4^{\mathrm{a}}$ & $6.6 \pm 0.3^{a}$ & $6.5 \pm 0.3^{a}$ & $6.6 \pm 0.3^{a}$ \\
\hline & 3 wks & $10.0 \pm 0.5^{\mathrm{a}}$ & $9.2 \pm 0.6^{c}$ & $9.5 \pm 0.6^{b}$ & $8.8 \pm 0.7^{\mathrm{d}}$ & $8.3 \pm 0.7^{\mathrm{e}}$ \\
\hline & $6 \mathrm{wks}$ & $15.2 \pm 1.1^{\mathrm{a}}$ & $13.8 \pm 1.0^{\mathrm{a}}$ & $13.4 \pm 1.0^{\mathrm{a}}$ & $12.5 \pm 1.0^{b}$ & $11.6 \pm 1.1^{\mathrm{c}}$ \\
\hline & 12 wks & $21.2 \pm 2.1^{\mathrm{a}}$ & $20.4 \pm 1.5^{b}$ & $19.2 \pm 1.9^{c}$ & $17.8 \pm 1.8^{\mathrm{d}}$ & $16.6 \pm 1.7^{\mathrm{e}}$ \\
\hline \multirow[t]{4}{*}{$\mathrm{BW}(\mathrm{g})$} & Initial & $2.9 \pm 0.5^{\mathrm{a}}$ & $2.9 \pm 0.5^{\mathrm{a}}$ & $3.0 \pm 0.5^{a}$ & $2.8 \pm 0.4^{\mathrm{a}}$ & $3.1 \pm 0.5^{\mathrm{a}}$ \\
\hline & 3 wks & $11.8 \pm 2.2^{\mathrm{a}}$ & $9.0 \pm 2.2^{c}$ & $10.0 \pm 2.0^{b}$ & $7.7 \pm 1.8^{\mathrm{d}}$ & $6.4 \pm 1.7^{\mathrm{e}}$ \\
\hline & 6 wks & $47.5 \pm 10.3^{\mathrm{a}}$ & $34.1 \pm 8.2^{\mathrm{a}}$ & $31.7 \pm 7.7^{\mathrm{a}}$ & $24.6 \pm 6.5^{b}$ & $19.8 \pm 6.0^{c}$ \\
\hline & $12 \mathrm{wks}$ & $132.8 \pm 41.2^{\mathrm{a}}$ & $116.9 \pm 27.4^{b}$ & $98.3 \pm 31.2^{c}$ & $73.9 \pm 25.3^{d}$ & $59.0 \pm 20.9^{\mathrm{e}}$ \\
\hline \multicolumn{2}{|c|}{ Specific growth rate $\left(\%\right.$ day $\left.^{-1}\right)$} & 4.39 & 4.24 & 4.03 & 3.75 & 3.40 \\
\hline \multicolumn{2}{|c|}{ Feed conversion ratio } & 0.99 & 0.96 & 1.00 & 1.23 & 1.14 \\
\hline
\end{tabular}

Values for FL and BW are represented by means \pm S.D. Different letters in row indicate statistically significant differences according to Kruskal-Wallis test and Mann-Whitney test with Holm's correction for post hoc comparison $(p<0.05)$. Abbreviations: FL, fork length; BW, body weight.

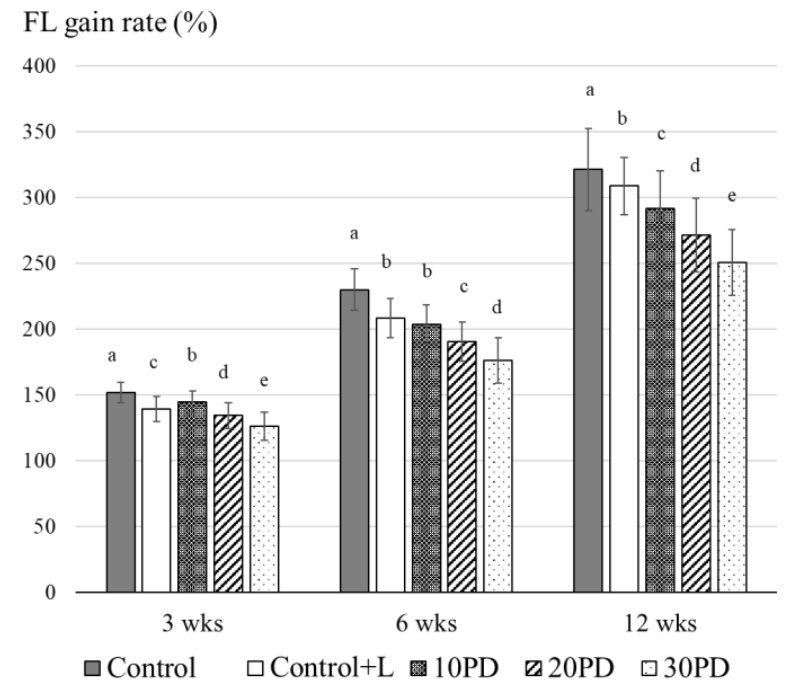

(a)

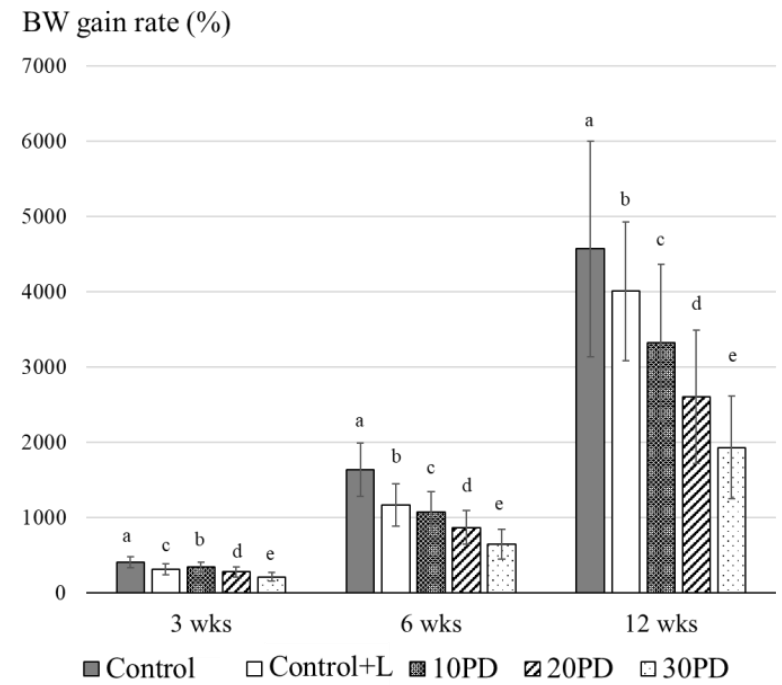

(b)

Figure 1. Fork length gain rate (a) and body weight gain rate (b) of yellowtail in feeding trial 1. Bars indicated S.D. Different letters indicate statistically significant differences according to Kruskal-Wallis test and Mann-Whitney test with Holm's correction for post hoc comparison $(p<0.05)$. Abbreviations: FL, fork length; BW, body weight.

Table 7. Growth of juvenile yellowtail in feeding trial 2.

\begin{tabular}{|c|c|c|c|c|c|c|c|}
\hline & & Control & Control+L & 10PD & 20PD & $10 \mathrm{CD}$ & $20 \mathrm{CD}$ \\
\hline \multirow{3}{*}{$N$} & Initial & 60 & 60 & 60 & 60 & 60 & 60 \\
\hline & $2.5 \mathrm{wks}$ & 57 & 60 & 58 & 58 & 60 & 59 \\
\hline & $5 \mathrm{wks}$ & 52 & 59 & 58 & 57 & 59 & 59 \\
\hline \multirow[t]{3}{*}{ FL (cm) } & Initial & $7.6 \pm 0.4^{\mathrm{a}}$ & $7.7 \pm 0.5^{\mathrm{a}}$ & $7.8 \pm 0.5^{\mathrm{a}}$ & $7.7 \pm 0.5^{\mathrm{a}}$ & $7.8 \pm 0.5^{\mathrm{a}}$ & $7.8 \pm 0.5^{\mathrm{a}}$ \\
\hline & $2.5 \mathrm{wks}$ & $11.4 \pm 0.7^{\mathrm{a}, \mathrm{b}}$ & $11.6 \pm 0.8^{\mathrm{a}}$ & $11.2 \pm 0.8^{\mathrm{a}, \mathrm{b}}$ & $10.7 \pm 0.8^{c}$ & $11.1 \pm 0.8^{b, c}$ & $11.2 \pm 0.7^{b}$ \\
\hline & 5 wks & $15.6 \pm 0.9^{\mathrm{a}}$ & $15.7 \pm 0.9^{\mathrm{a}}$ & $14.8 \pm 1.1^{\mathrm{b}}$ & $13.8 \pm 1.1^{c}$ & $14.8 \pm 1.0^{\mathrm{b}}$ & $14.6 \pm 0.9^{b}$ \\
\hline \multirow{3}{*}{ BW (g) } & Initial & $5.0 \pm 1.0^{\mathrm{a}}$ & $5.4 \pm 1.0^{a}$ & $5.4 \pm 1.2^{\mathrm{a}}$ & $5.2 \pm 1.2^{\mathrm{a}}$ & $5.4 \pm 1.2^{\mathrm{a}}$ & $5.4 \pm 1.2^{\mathrm{a}}$ \\
\hline & $2.5 \mathrm{wks}$ & $18.2 \pm 3.5^{\mathrm{a}, \mathrm{b}}$ & $18.7 \pm 4.1^{\mathrm{a}}$ & $16.8 \pm 3.9^{\mathrm{a}, \mathrm{b}}$ & $14.6 \pm 3.7^{c}$ & $16.7 \pm 3.5^{b, c}$ & $17.0 \pm 3.7^{a, b}$ \\
\hline & 5 wks & $50.8 \pm 9.8^{a}$ & $49.6 \pm 10.1^{a}$ & $41.8 \pm 10.6^{b}$ & $32.9 \pm 8.3^{c}$ & $41.9 \pm 9.8^{\mathrm{b}}$ & $39.6 \pm 8.8^{b}$ \\
\hline \multicolumn{2}{|c|}{ Specific growth rate $\left(\%\right.$ day $\left.^{-1}\right)$} & 6.61 & 6.32 & 5.85 & 5.25 & 5.85 & 5.69 \\
\hline \multicolumn{2}{|c|}{ Feed conversion ratio } & 1.06 & 1.15 & 1.07 & 0.97 & 1.10 & 1.09 \\
\hline
\end{tabular}

Values for FL and BW are represented by means \pm S.D. Different letters in row indicate statistically significant differences according to Kruskal-Wallis test and Mann-Whitney test with Holm's correction for post hoc comparison $(p<0.05)$. Abbreviations: FL, fork length; BW, body weight. 
Intestinal length ratio (\%)

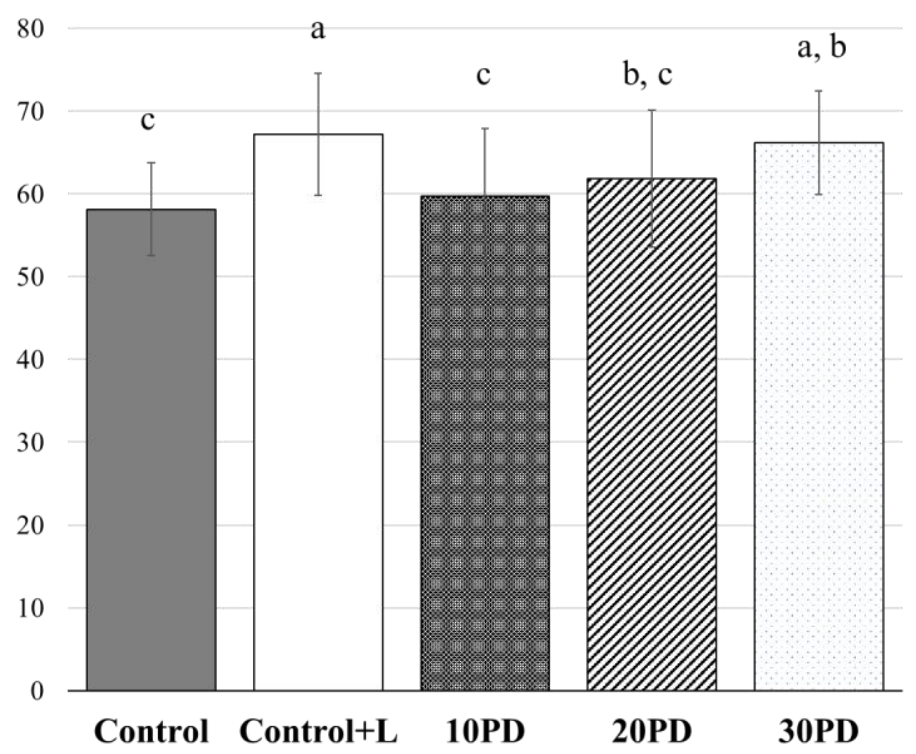

Figure 2. Intestinal length ratio of yellowtail in feeding trial 1. Bars indicated S.D. Different letters indicate statistically significant differences according to Kruskal-Wallis test and Mann-Whitney test with Holm's correction for post hoc comparison $(p<0.05)$.

FL gain rate $(\%)$

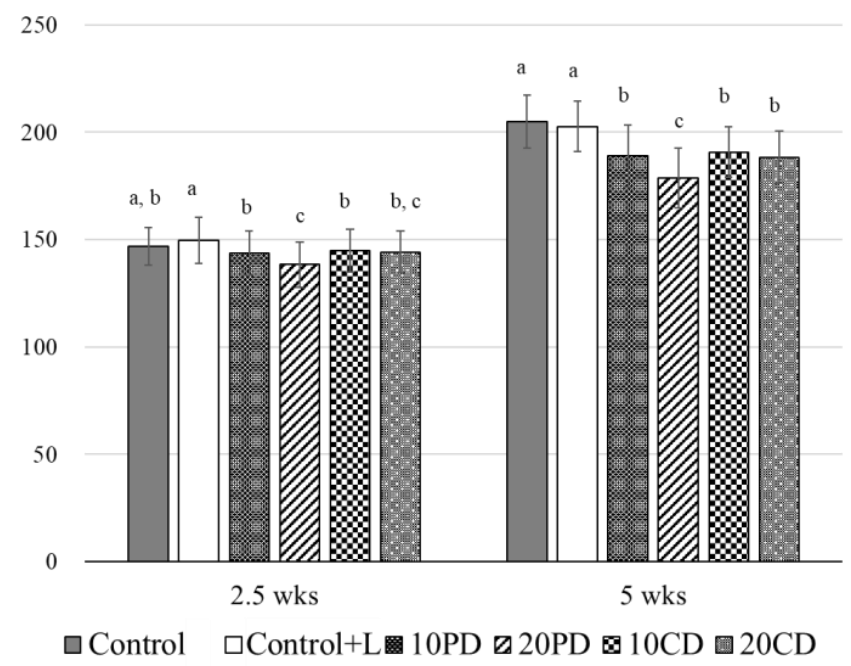

(a)

\section{BW gain rate $(\%)$}

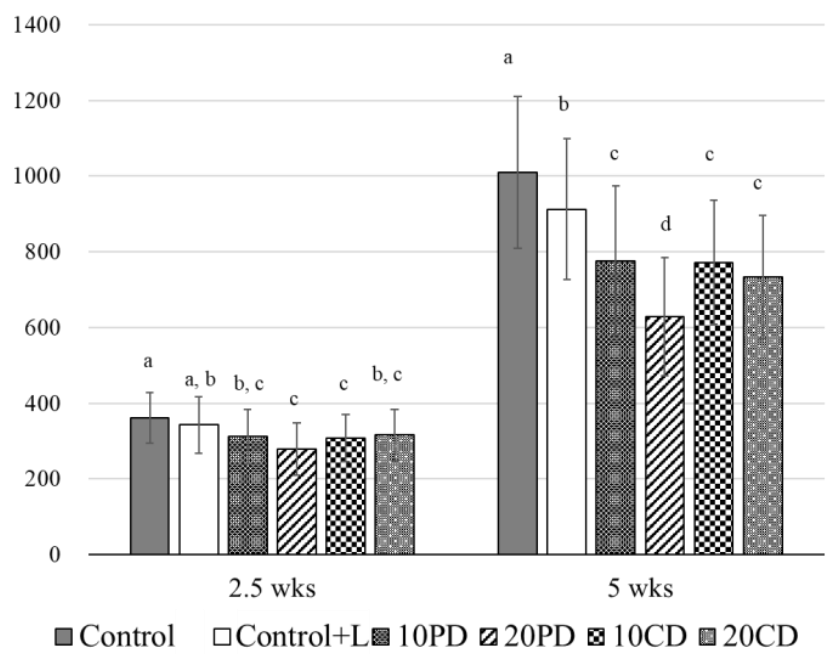

(b)

Figure 3. Fork length gain rate (a) and body weight gain rate (b) of yellowtail in feeding trial 2. Bars indicated S.D. Different letters indicate statistically significant differences according to Kruskal-Wallis test and Mann-Whitney test with Holm's correction for post hoc comparison $(p<0.05)$. Abbreviations: FL, fork length; BW, body weight.

\section{Discussion}

In this study, we demonstrated the feeding trials to explore the potential of BSF larvae meal for yellowtail aquaculture; however, the results showed adverse effects on growth with a diet of even 10\% BSF larvae meal content and 11.1\% FM substitution. Although other studies of different fish species have concluded that BSF larvae meal could replace FM, the levels of BSF larvae meal included in the diets investigated were limited. Diets with around $10 \%$ full-fat BSF larvae included resulted in no adverse effects in Nile tilapia (Oreochromis niloticus) [25], while those with partially defatted BSF larvae resulted in the same or higher 
growth in African catfish (Clarias gariepinus) [26], Jian carp (Cyprinus carpio) [27], and rice field eel (Monopterus albus) [28]. On the other hand, several studies investigated diets with a high content of BSF larvae. Using $29 \%$ full-fat BSF larvae meal could completely replace FM for climbing perch (Anabas testudineus) [29], while a diet with more than 30\% defatted BSF larvae meal negatively affected yellow catfish (Pelteobagrus fulvidraco) [30] and Siberian sturgeon (Acipenser baerii) [31]. Although a diet that included $40 \%$ defatted BSF larvae meal and 50\% FM substitution did not affect the growth of rainbow trout (Oncorhynchus mykiss) [32], that with 21\% full-fat BSF larvae inclusion resulted in adverse effects [33]. In a meta-analysis of 16 peer-reviewed journal publications about BSF, diets that included levels of more than $29 \%$ ( $\pm 3 \%$ ) BSF larvae depressed growth performance in fish [34]. Therefore, it is known that growth tends to be reduced in fish fed on diets containing high levels of BSF. However, compared with these previous studies, it should be noted that growth retardation in yellowtail occurred with just $10 \%$ BSF larvae meal inclusion and $11.1 \%$ FM substitution.

Chitin, a linear homopolymer of $\beta(1-4)$-linked $\mathrm{N}$-acetylglucosamine units and a major constituent of insect cuticles, is thought to result in growth reduction in marine fish because it is difficult to digest [11]. Of the total nitrogen in BSF prepupae, 9.4\% is reported to be derived from chitin [35]. As the nitrogen in the PDBM used in this study was $7.8 \%$, the amounts of chitin and protein were estimated to be approximately $10.7 \%$ and $41.4 \%$, respectively. The total amino acids in the PDBM comprised $40.5 \%$ on a dried basis, so this estimate seems to be reasonable. However, the BSF larvae meal in the test diets was only $10-20 \%$, so the content of chitin derived from BSF in the test diets was only between $1-2 \%$. A diet supplemented with $10 \%$ chitin does not inhibit growth, and chitinase enzyme activity has been detected in the stomach of yellowtails [36]. Therefore, chitin was not thought to be a major factor responsible for causing the significant reduction in growth.

One factor derived from BSF larvae that can affect fish growth seems to be the fatty acid profile of the diet. Crude fats of BSF larvae and pre-pupae in diets are known to significantly alter gut microbiota in rainbow trout [37]. The BSF larvae meal used in the present study was rich in lauric acid and it comprised $30 \%$ of total fatty acids. Lauric acid has a high melting point and is solid at room temperature. Diets that are rich in lauric acid do not affect growth in freshwater rainbow trout [38,39] or Atlantic salmon [40]. In addition, as long as the fatty acid composition in the diet meets the essential nutrition requirements, the diet including lauric acid at $14 \%$ of total fatty acid promotes the growth of the yellow croaker (Larimichthys crocea) [41]. In contrast, our findings showed that dietary intake of lauric acid could negatively affect the growth of yellowtails. However, the growth in fish fed on diets containing BSF larvae meal was significantly decreased than that in fish fed on the Control+L diet including lauric acid. These results indicate that factors other than fatty acids affect growth. In feeding trial 1, we found that intestinal length ratios in fish fed on diets that included lauric acid were higher than those in the Control, and the length ratios increased with increasing PDBM content. Enlargements in the intestine of fish fed on BSF larvae have also been reported in Atlantic salmon [9], so the BSF larvae meal content or difference in the fatty acid profile of a diet might induce morphological changes in the intestines of fish. No difference in the intestinal length was observed during feeding trial 2 (data not shown). This might be due to the difference in the durations of the feeding period.

The effects of fat fractions other than fatty acids from BSF larvae on fish growth should be concerned. We observed that the growth of fish in the 20CD group was significantly higher than that of the 20PD group, and that it was comparable with that of the 10PD group. Thus, it seems as though the fat fraction of BSF larvae would depress fish growth. In our previous studies with red seabream (Pagrus major), yellow mealworm (Tenebrio molitor) and housefly (Musca domestica) larvae defatted with hexane could successfully replace FM at proportions of $65 \%$ and $70 \%$, respectively, in the diet [22,23]. Additionally, dietary intake of catechol identified in fat fraction from housefly larvae causes a reduction in growth and morphological alterations in the intestines in fish [23]. In these studies, as in the present 
study, fat fractions of insects could possibly depress fish growth. As the diets including CDBM were inferior to the control diets, it is not only the fat fraction but also other factors in BSF larvae that must depress fish growth. As the fat fraction of BSF larvae showed an enhancement of innate immunity, allowing the use of elevated levels of plant proteins in the diet of rainbow trout [42], there is no doubt that differences in the sensitivity among fish species lead to different results.

\section{Conclusions}

We conducted the feeding trials with juvenile yellowtail for the purpose of replacing FM with BSF larvae meal. The fish growth was significantly reduced in accordance with content of BSF larvae meal. However, the growth of fish fed on 20\% CDBM was comparable with those on $10 \%$ PDBM, so we found that removal of fat fraction from the meal could improve the fish growth. Regardless of finding negative effects on yellowtail growth in this study, insects are still considered to be useful feed ingredients. Moreover, defatted BSF larvae meal could be beneficial in FM replacement.

Author Contributions: Conceptualization, A.I. and T.M.; methodology, A.I.; validation, A.I.; formal analysis, A.I., M.-F.-Z.A., T.T. and T.M; investigation, A.I., M.-F.-Z.A., T.T. and T.M; data curation, A.I.; writing—original draft preparation, A.I.; writing—review and editing, T.M.; supervision, C.M. and T.M.; funding acquisition, T.M. All authors have read and agreed to the published version of the manuscript.

Funding: This research was funded by the Japan Science and Technology Agency, JSPS Kakenhi from 2018 to 2021 (18H03960).

Institutional Review Board Statement: The study protocol was approved by the Institutional Animal Care and Use Committee (IACUC) of Ehime University (Permit Number: 3908).

Informed Consent Statement: Not applicable.

Data Availability Statement: The data that support the findings of this study are available from the corresponding author, upon reasonable request.

Acknowledgments: We would like to thank Shintoa Corporation for providing black soldier fly meal. We also thank the staff at the Laboratory of Fish Reproductive Physiology, Graduate School of Agriculture, Ehime University.

Conflicts of Interest: The authors declare no conflict of interest.

\section{References}

1. Tacon, A.G.J.; Metian, M. Feed Matters: Satisfying the Feed Demand of Aquaculture. Rev. Fish. Sci. Aquac. 2015, 23, 1-10. [CrossRef]

2. Alder, J.; Campbell, B.; Karpouzi, V.; Kaschner, K.; Pauly, D. Forage Fish: From Ecosystems to Markets. Annu. Rev. Environ. Resour. 2008, 33, 153-166. [CrossRef]

3. Makkar, H.P.S.; Tran, G.; Heuzé, V.; Ankers, P. State-of-the-art on use of insects as animal feed. Anim. Feed Sci. Technol. 2014, 197, 1-33. [CrossRef]

4. Shafique, L.; Abdel-Latif, H.M.R.; Hassan, F.; Alagawany, M.; Naiel, M.A.E.; Dawood, M.A.O.; Yilmaz, S.; Liu, Q. The Feasibility of Using Yellow Mealworms (Tenebrio molitor): Towards a Sustainable Aquafeed Industry. Animals 2021, 11, 811. [CrossRef]

5. Ido, A.; Iwai, T.; Ito, K.; Ohta, T.; Mizushige, T.; Kishida, T.; Miura, C.; Miura, T. Dietary effects of housefly (Musca domestica) (Diptera: Muscidae) pupae on the growth performance and the resistance against bacterial pathogen in red sea bream (Pagrus major) (Perciformes: Sparidae). Appl. Entomol. Zool. 2015, 50, 213-221. [CrossRef]

6. Ali, M.F.Z.; Ohta, T.; Ido, A.; Miura, C.; Miura, T. The Dipterose of Black Soldier Fly (Hermetia illucens) Induces Innate Immune Response through Toll-Like Receptor Pathway in Mouse Macrophage RAW264.7 Cells. Biomolecules 2019, 9, 677. [CrossRef]

7. Chaklader, M.R.; Siddik, M.A.B.; Fotedar, R.; Howieson, J. Insect larvae, Hermetia illucens in poultry by-product meal for barramundi, Lates calcarifer modulates histomorphology, immunity and resistance to Vibrio harveyi. Sci. Rep. 2019, 9, 1-15. [CrossRef]

8. Abdel-Latif, H.M.R.; Abdel-Tawwab, M.; Khalil, R.H.; Metwally, A.A.; Shakweer, M.S.; Ghetas, H.A.; Khallaf, M.A. Black soldier fly (Hermetia illucens) larvae meal in diets of European seabass: Effects on antioxidative capacity, non-specific immunity, transcriptomic responses, and resistance to the challenge with Vibrio alginolyticus. Fish. Shellfish Immunol. 2021, 111, 111-118. [CrossRef] 
9. Li, Y.; Kortner, T.M.; Chikwati, E.M.; Belghit, I.; Lock, E.J.; Krogdahl, Å. Total replacement of fish meal with black soldier fly (Hermetia illucens) larvae meal does not compromise the gut health of Atlantic salmon (Salmo salar). Aquaculture 2020, 520, 734967. [CrossRef]

10. Belghit, I.; Liland, N.S.; Gjesdal, P.; Biancarosa, I.; Menchetti, E.; Li, Y.; Waagbø, R.; Krogdahl, Å.; Lock, E.J. Black soldier fly larvae meal can replace fish meal in diets of sea-water phase Atlantic salmon (Salmo salar). Aquaculture 2019, 503, 609-619. [CrossRef]

11. Kroeckel, S.; Harjes, A.-G.E.; Roth, I.; Katz, H.; Wuertz, S.; Susenbeth, A.; Schulz, C. When a turbot catches a fly: Evaluation of a pre-pupae meal of the Black Soldier Fly (Hermetia illucens) as fish meal substitute-Growth performance and chitin degradation in juvenile turbot (Psetta maxima). Aquaculture 2012, 364-365, 345-352. [CrossRef]

12. Magalhães, R.; Sánchez-López, A.; Leal, R.S.; Martínez-Llorens, S.; Oliva-Teles, A.; Peres, H. Black soldier fly (Hermetia illucens) pre-pupae meal as a fish meal replacement in diets for European seabass (Dicentrarchus labrax). Aquaculture 2017, 476, 79-85. [CrossRef]

13. Wang, G.; Peng, K.; Hu, J.; Yi, C.; Chen, X.; Wu, H.; Huang, Y. Evaluation of defatted black soldier fly (Hermetia illucens L.) larvae meal as an alternative protein ingredient for juvenile Japanese seabass (Lateolabrax japonicus) diets. Aquaculture 2019, 507, 144-154 [CrossRef]

14. Abdel-Tawwab, M.; Khalil, R.H.; Metwally, A.A.; Shakweer, M.S.; Khallaf, M.A.; Abdel-Latif, H.M.R. Effects of black soldier fly (Hermetia illucens L.) larvae meal on growth performance, organs-somatic indices, body composition, and hemato-biochemical variables of European sea bass, Dicentrarchus labrax. Aquaculture 2020, 522, 735136. [CrossRef]

15. Sicuro, B.; Luzzana, U. The State of Seriola spp. Other Than Yellowtail (S. quinqueradiata) Farming in the World. Rev. Fish. Sci. Aquac. 2016, 24, 314-325. [CrossRef]

16. Nakada, M. Capture-based aquaculture of yellowtail. Capture Based Aquac. Glob. Overv. FAO Fish. Tech. Pap. 2008, 508, 199-215.

17. Miura, C.; Yoshihara, Y.; Shimizu-Yamaguchi, S.; Hayashi, D.; Hamada, K.; Takeda, Y.; Miura, M.; Miura, T. Controlled feeding alleviates the reduced growth associated with spawning in farmed yellowtail (Seriola quinqueradiata). Aquaculture 2014, 424-425, 10-17. [CrossRef]

18. Watanabe, T.; Aoki, H.; Shimamoto, K.; Hadzuma, M.; Maita, M.; Yamagata, Y.; Kiron, V.; Satoh, S. A Trial to Culture Yellowtail with Non-fishmeal Diets. Fish. Sci. 1998, 64, 505-512. [CrossRef]

19. Sarker, M.S.A.; Satoh, S.; Kamata, K.; Haga, Y.; Yamamoto, Y. Partial replacement of fish meal with plant protein sources using organic acids to practical diets for juvenile yellowtail, Seriola quinqueradiata. Aquac. Nutr. 2012, 18, 81-89. [CrossRef]

20. Nguyen, H.P.; Khaoian, P.; Furutani, T.; Nagano, J.; Fukada, H.; Masumoto, T. Effects of alcohol extract of defatted soybean meal on growth performance and digestive physiology of yellowtail Seriola quinqueradiata. Fish. Sci. 2017, 83, 99-106. [CrossRef]

21. Murashita, K.; Matsunari, H.; Fukada, H.; Suzuki, N.; Furuita, H.; Oku, H.; Rønnestad, I.; Yoshinaga, H.; Yamamoto, T. Effect of a plant-based low-fishmeal diet on digestive physiology in yellowtail Seriola quinqueradiata. Aquaculture 2019, 506, 168-180. [CrossRef]

22. Ido, A.; Hashizume, A.; Ohta, T.; Takahashi, T.; Miura, C.; Miura, T. Replacement of Fish Meal by Defatted Yellow Mealworm (Tenebrio molitor) Larvae in Diet Improves Growth Performance and Disease Resistance in Red Seabream (Pargus major). Animals 2019, 9, 100. [CrossRef] [PubMed]

23. Hashizume, A.; Ido, A.; Ohta, T.; Thiaw, S.T.; Morita, R.; Nishikawa, M.; Takahashi, T.; Miura, C.; Miura, T. Housefly (Musca domestica) Larvae Preparations after Removing the Hydrophobic Fraction Are Effective Alternatives to Fish Meal in Aquaculture Feed for Red Seabream (Pagrus major). Fishes 2019, 4, 38. [CrossRef]

24. AOAC international. Official Methods of Analysis of AOAC International, 20th ed.; Latimer, W.G., Ed.; AOAC International: Gaithersburg, MD, USA, 2016; ISBN 0935584870.

25. Tippayadara, N.; Dawood, M.A.O.; Krutmuang, P.; Hoseinifar, S.H.; Van Doan, H.; Paolucci, M. Replacement of Fish Meal by Black Soldier Fly (Hermetia illucens) Larvae Meal: Effects on Growth, Haematology, and Skin Mucus Immunity of Nile Tilapia, Oreochromis niloticus. Animals 2021, 11, 193. [CrossRef]

26. Fawole, F.J.; Adeoye, A.A.; Tiamiyu, L.O.; Ajala, K.I.; Obadara, S.O.; Ganiyu, I.O. Substituting fishmeal with Hermetia illucens in the diets of African catfish (Clarias gariepinus): Effects on growth, nutrient utilization, haemato-physiological response, and oxidative stress biomarker. Aquaculture 2020, 518, 734849. [CrossRef]

27. Li, S.; Ji, H.; Zhang, B.; Zhou, J.; Yu, H. Defatted black soldier fly (Hermetia illucens) larvae meal in diets for juvenile Jian carp (Cyprinus carpio var. Jian): Growth performance, antioxidant enzyme activities, digestive enzyme activities, intestine and hepatopancreas histological. Aquaculture 2017, 477, 62-70. [CrossRef]

28. Hu, Y.; Huang, Y.; Tang, T.; Zhong, L.; Chu, W.; Dai, Z.; Chen, K.; Hu, Y. Effect of partial black soldier fly (Hermetia illucens L.) larvae meal replacement of fish meal in practical diets on the growth, digestive enzyme and related gene expression for rice field eel (Monopterus albus). Aquac. Rep. 2020, 17, 100345. [CrossRef]

29. Vongvichith, B.; Morioka, S.; Sugita, T.; Phousavanh, N.; Phetsanghanh, N.; Chanthasone, P.; Pommachan, P.; Nakamura, S. Evaluation of the efficacy of aquaculture feeds for the climbing perch Anabas testudineus: Replacement of fishmeal by black soldier fly Hermetia illucens prepupae. Fish. Sci. 2020, 86, 145-151. [CrossRef]

30. Xiao, X.; Jin, P.; Zheng, L.; Cai, M.; Yu, Z.; Yu, J.; Zhang, J. Effects of black soldier fly (Hermetia illucens) larvae meal protein as a fishmeal replacement on the growth and immune index of yellow catfish (Pelteobagrus fulvidraco). Aquac. Res. 2018, 49, 1569-1577. [CrossRef] 
31. Caimi, C.; Renna, M.; Lussiana, C.; Bonaldo, A.; Gariglio, M.; Meneguz, M.; Dabbou, S.; Schiavone, A.; Gai, F.; Elia, A.C.; et al. First insights on Black Soldier Fly (Hermetia illucens L.) larvae meal dietary administration in Siberian sturgeon (Acipenser baerii Brandt) juveniles. Aquaculture 2020, 515, 734539. [CrossRef]

32. Renna, M.; Schiavone, A.; Gai, F.; Dabbou, S.; Lussiana, C.; Malfatto, V.; Prearo, M.; Capucchio, M.T.; Biasato, I.; Biasibetti, E.; et al. Evaluation of the suitability of a partially defatted black soldier fly (Hermetia illucens L.) larvae meal as ingredient for rainbow trout (Oncorhynchus mykiss Walbaum) diets. J. Anim. Sci. Biotechnol. 2017, 8, 1-13. [CrossRef] [PubMed]

33. Cardinaletti, G.; Randazzo, B.; Messina, M.; Zarantoniello, M.; Giorgini, E.; Zimbelli, A.; Bruni, L.; Parisi, G.; Olivotto, I.; Tulli, F. Effects of Graded Dietary Inclusion Level of Full-Fat Hermetia illucens Prepupae Meal in Practical Diets for Rainbow Trout (Oncorhynchus mykiss). Animals 2019, 9, 251. [CrossRef]

34. Hua, K. A meta-analysis of the effects of replacing fish meals with insect meals on growth performance of fish. Aquaculture 2021, 530, 735732. [CrossRef]

35. Caligiani, A.; Marseglia, A.; Leni, G.; Baldassarre, S.; Maistrello, L.; Dossena, A.; Sforza, S. Composition of black soldier fly prepupae and systematic approaches for extraction and fractionation of proteins, lipids and chitin. Food Res. Int. 2018, 105, 812-820. [CrossRef] [PubMed]

36. Kono, M.; Matsui, T.; Shimizu, C. Effect of Chitin, Chitosan, and Cellulose as Diet Supplements on the Growth of Cultured Fish. Nippon Suisan Gakkaish 1987, 53, 125-129. [CrossRef]

37. Huyben, D.; Vidaković, A.; Werner Hallgren, S.; Langeland, M. High-throughput sequencing of gut microbiota in rainbow trout (Oncorhynchus mykiss) fed larval and pre-pupae stages of black soldier fly (Hermetia illucens). Aquaculture 2019, 500, 485-491. [CrossRef]

38. Cláudia Figueiredo-Silva, A.; Kaushik, S.; Terrier, F.; Schrama, J.W.; Médale, F.; Geurden, I. Link between lipid metabolism and voluntary food intake in rainbow trout fed coconut oil rich in medium-chain TAG. Br. J. Nutr. 2012, 107, 1714-1725. [CrossRef]

39. Ballestrazzi, R.; Rainis, S.; Maxia, M. The replacement of fish oil with refined coconut oil in the diet of large rainbow trout (Oncorhynchus mykiss). Ital. J. Anim. Sci. 2006, 5, 155-164. [CrossRef]

40. Belghit, I.; Waagbø, R.; Lock, E.-J.; Liland, N.S. Insect-based diets high in lauric acid reduce liver lipids in freshwater Atlantic salmon. Aquac. Nutr. 2019, 25, 343-357. [CrossRef]

41. Ding, T.; Xu, N.; Liu, Y.; Li, X.; Xiang, X.; Xu, D.; Yao, C.; Liu, Q.; Yin, Z.; Mai, K.; et al. Optimal amounts of coconut oil in diets improve the growth, antioxidant capacity and lipid metabolism of large yellow croaker (Larimichthys crocea). Mar. Life Sci. Technol. 2020, 2, 376-385. [CrossRef]

42. Kumar, V.; Fawole, F.J.; Romano, N.; Hossain, M.S.; Labh, S.N.; Overturf, K.; Small, B.C. Insect (black soldier fly, Hermetia illucens) meal supplementation prevents the soybean meal-induced intestinal enteritis in rainbow trout and health benefits of using insect oil. Fish. Shellfish Immunol. 2021, 109, 116-124. [CrossRef] [PubMed] 